\title{
The glacial buzzsaw and its limitations: mountain glaciation in British Columbia and in Britain
}

\author{
Department of Geography \\ Durham University \\ Durham, UK \\ i.s.evans@durham.ac.uk
}

Ian Evans

\author{
Department of Geography \\ Faculty of Geography and History \\ Ştefan cel Mare University of Suceava \\ Suceava, Romania
}

\begin{abstract}
Erosion by warm-based glaciers is highly effective and has produced distinctive mountain landscapes. Downward erosion dominates, but headward erosion by recession of cirque headwalls is sufficient to displace drainage divides and lower summits on cirque crests. This 'glacial buzzsaw', however, is not universal: it does not apply in the many areas where low-gradient surfaces survive above cirques. It applies patchily in British Columbia, Britain and Romania.
\end{abstract}

Keywords—glacial buzzsaw; mountain glaciation; Bristish Columbia; Britain

There is now general agreement that glacial erosion can be faster than fluvial erosion, so long as ice is 'warm' and wet-based. In fact, glacial erosion rates increase with the amount of basal water [1] and with the rate of basal sliding: hence in Patagonia there is a maximum at $44^{\circ} \mathrm{S}$, where precipitation was greatest during the Last Glacial Maximum [2]. In a simple glacier, ice discharge and rates of basal sliding are greatest at the Equilibrium Line (E.L.). But in a large valley glacier system, tributaries converge to give greater discharges further down the trunk glacier: together with the increasing amount of basal water, this gives greater erosion downstream, where major troughs and rock basins are eroded. Considerable headward erosion is observed also at glacier sources, often on one side of a mountain range. This requires not just glacial abrasion, but also glacial quarrying and/or headwall collapse by rock mass failure. The balance between headward and downward glacial erosion seems to have varied at different stages of Quaternary glacial history [3].

The buzzsaw hypothesis asserts that rapid glacial erosion around the E.L. Altitude (ELA) tends to truncate mountain ranges and control the altitudes that summits can reach [4]. This implies that summits are on the edge of cirques and in course of being lowered as cirques develop. This is most clearly the case where sharp ridges delimit contiguous, intersecting cirques, as for example in the
Washington Cascades and the Southern Alps of New Zealand. It can apply also where contiguous cirques on one side of a ridge are extending at the expense of the opposite slope. It cannot apply where gentle summit slopes survive above the cirques, as in the Godeanu and Parîng Mountains [5]. As such gentle summits rise little above cirque headwalls, the general relation between summit altitudes and cirque floor altitudes [6] applies here as well as where ridges are sharp: thus it does not provide support for the buzzsaw hypothesis [7]. Support may be provided, however, by geomorphological mapping and detailed hypsometric analysis [8].

The southern Coast Mountains of British Columbia are deeply dissected by glacial erosion, both by ice sheets and local glaciers. Ridges are sharp, and mainly with intersecting cirques, as in the Bendor Range and farther west. They have clearly been lowered by headward cirque erosion, yet the evidence for a glacial buzzsaw is weaker than to the south in the Washington Cascades. Cirque floors follow the trend of ELA, which rises by $1000 \mathrm{~m}$ from the coast to the dry interior, but summit maxima do not. Thus as you go west or southwestward into the mountains, cirque glaciers are replaced by valley glaciers and eventually icefields as mountains rise higher above ELA (Fig.1). This implies that uplift has been rapid enough to take these mountains through the zone of most effective erosion. That is more evidently the case with the largest icefields of middle latitudes: Patagonia, the Karakoram and the St. Elias of Alaska, which are areas of very rapid glacial erosion. It is likely that rapid Quaternary uplift in these three areas carried mountains quickly through the zone of rapid glacial erosion, into that of cold ice frozen to its bed. This produced 'Teflon peaks', rapidly uplifted into the zone of cold, non-erosive ice, while ice streams eroded deeply in the valleys between. 


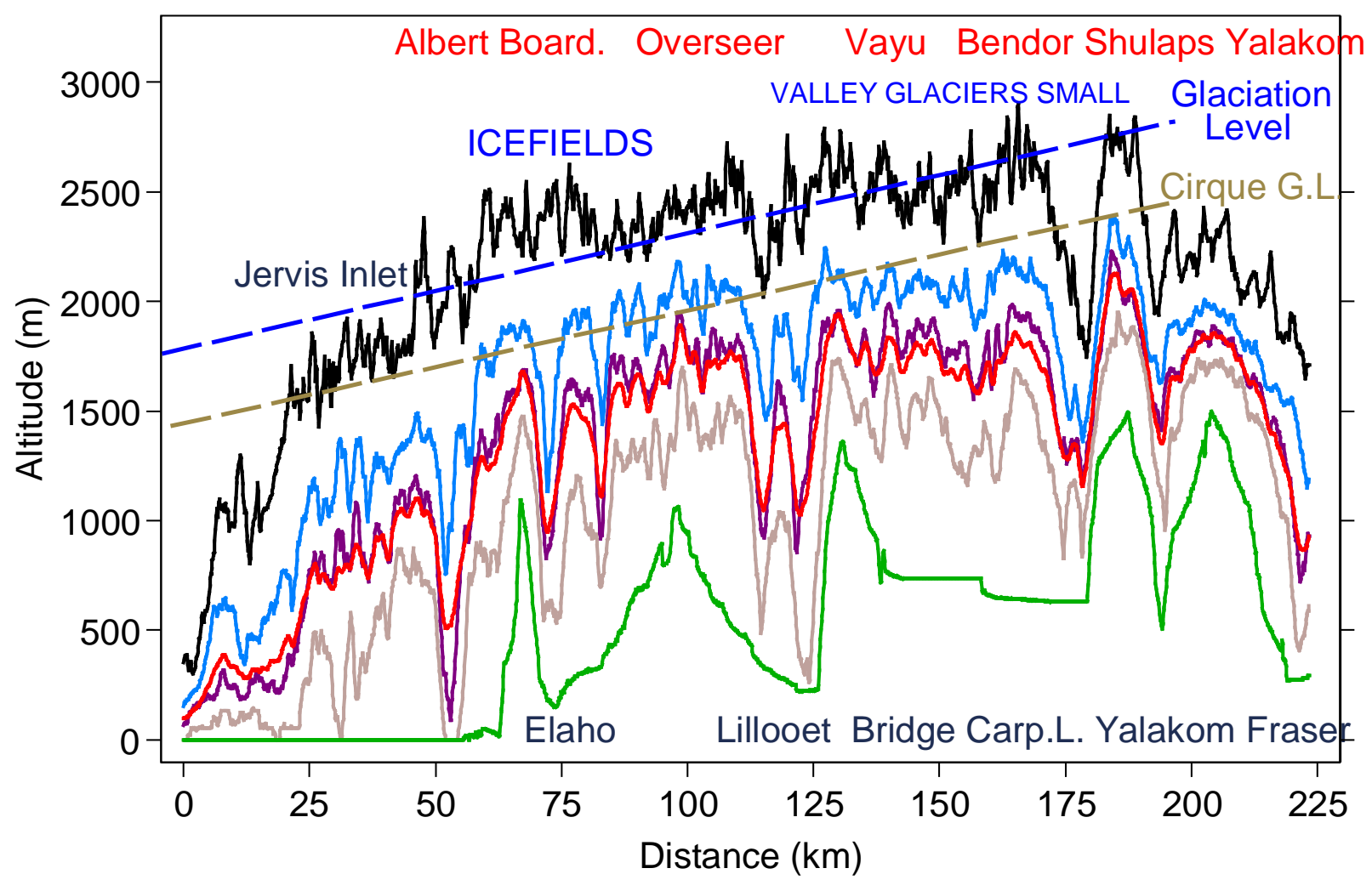

$\longrightarrow \max \longrightarrow$ p75 median- mean $\longrightarrow$ p25 $-\min$

Fig. 1. Swath profile across southern Coast Mountains, B.C.: $50 \mathrm{~km}$ bands every $100 \mathrm{~m}$. Mountain names in red, valleys in navy blue. Hypsometry from P. Bandura. (G.L. = Glaciation level, generally 200-300 m above ELA. Carp. L. = Carpenter Lake.).

Glaciation on the landward side of the Coast Mountains is strongly asymmetric in that glaciers formed and eroded cirques only on the shaded or leeward side of a mountain range.

Headward extension of adjacent cirques on a ridge leads to displacement of the divide, sometimes by $2 \mathrm{~km}$ or more [9], lowering ridge and summit altitudes in accordance with the buzzsaw hypothesis. Such forms of local glaciation have survived immersion in the Cordilleran Ice sheet, which overwhelmed almost all the Coast Mountains at the glacial maximum and created throughtroughs. Headward erosion by a few $\mathrm{km}$ is important in a number of other areas where glaciation was asymmetric (Table I). This considerable headwall retreat (cirque lengthening) supports the glacial 'buzzsaw', as summits are on cirque crests and are clearly being lowered.

In Britain, glaciation was asymmetric with a general northeastward tendency in cirque aspect reflecting increased glacier balance on both poleward and leeward slopes. A recent study mapped the distribution of cirques throughout Britain and Ireland [10]. It finds 1139 in Scotland, 637 in Ireland, 260 in Wales and 172 in England. As in British Columbia, cirques survived more extensive ice sheet glaciation at glacial maxima: only a few, as in the central fells of the English Lake District, show considerable modification by overriding ice. The 2208 cirques average $774 \mathrm{~m}$ long, $786 \mathrm{~m}$ wide and $283 \mathrm{~m}$ deep.
TABLE I. AMOUNTS OF HEADWARD EXTENSION OF VALLEYS, WITH DIVIDE DISPLACEMENT. (FOR REFERENCES, SEE [11])

\begin{tabular}{|c|c|c|}
\hline displacement & region & authors \\
\hline 1.5 to $3 \mathrm{~km}$ & $\begin{array}{l}\text { Terrace, West } \\
\text { Central B.C. }\end{array}$ & Hanson 1924 \\
\hline up to $2.5 \mathrm{~km}$ & $\begin{array}{c}\text { Shulaps Range, } \\
\text { B.C. }\end{array}$ & Evans 1972 \\
\hline 2 to $5 \mathrm{~km}$ & Bendor Range, B.C. & Evans 1972 \\
\hline 1 to $2 \mathrm{~km}$ & $\begin{array}{l}\text { Yohetta Range, } \\
\text { B.C. }\end{array}$ & Evans \\
\hline up to $1 \mathrm{~km}$ & $\begin{array}{c}\text { Kenai \& Talkeetna, } \\
\text { S. Alaska }\end{array}$ & Tuck 1935 \\
\hline up to $2.5 \mathrm{~km}$ & Sa. Nevada & $\begin{array}{l}\text { Brocklehurst \& Whipple } \\
2002\end{array}$ \\
\hline 0.9 to $4.4 \mathrm{~km}$ & Kyrgyz Ra., C. Asia & Oskin \& Burbank 2005 \\
\hline
\end{tabular}

Glacial cirques are eroded mainly by local mountain glaciers, and these lasted longer during the build-up of glacier cover (as deglaciation has normally been more rapid than build-up). Thus they provide valuable evidence of climatic conditions during the initiation of glaciation, a period for which glacial deposits are lacking [12, 13]. In Britain and Ireland, cirques are lower near west coasts, but low also near Irish Sea coasts in Wales, the Lake District and eastern Ireland (Wicklow, Mourne and MonavullaghComeragh Mountains). This implies environmental conditions colder but otherwise similar to the present day, with moisture (then snow, now rain) brought by west and southwest winds. Cirques near west coasts are also deeper, 
suggesting greater erosion by maritime glaciers with greater throughputs of ice.

In Scotland, Ireland, Wales and England we find both mountain ranges with intersecting ridges, where cirque development is lowering summits (e.g. the Cuillins and Snowdon), and others with summit plateaux above cirque crests (e.g. Cairngorms, Wicklows, Carneddau and High Street). The buzzsaw hypothesis is applicable to the former, but their proximity to the latter suggests that modern summit lowering has not been great. A third situation is found in the Helvellyn range, with cirques on the east slope lowering summits by eroding into the gentler west-facing slopes.

Romania has never suffered ice sheet glaciation, but its mountains are similar to Britain's in having a mixture of these three situations [5]. It is clear that the glacial buzzsaw operates locally, but not as universally as proposed by [6]. Its applicability may depend on the rate of uplift during the Quaternary and the initial height of mountains in relation to Quaternary snowlines.

\section{REFERENCES}

[1] R.A. Fernandez, J.B. Anderson, J.S. Wellner, R.L. Minzoni, B. Hallet, and R.T. Smith, "Latitudinal variation in glacial erosion rates from Patagonia and the Antarctic Peninsula $\left(46^{\circ} \mathrm{S}-65^{\circ} \mathrm{S}\right)$ " Geological Society of America Bulletin, vol. 128, no. 5-6, pp.10001023, 2016.

[2] F. Herman and M. Brandon, "Mid-latitude glacial erosion hotspot related to equatorial shifts in southern Westerlies” Geology, vol. 43, no. 11, pp. 987-990, 2015.

[3] V.K. Pedersen and D.L. Egholm, "Glaciations in response to climate variations preconditioned by evolving topography" Nature, vol. 493, pp. 206-210, 2013.
[4] S.G. Mitchell and D.R. Montgomery, "Influence of a glacial buzzsaw on the height and morphology of the Cascade Range in central Washington State, USA”, Quaternary Research, vol. 65, pp. 96-107, 2006.

[5] M. Mîndrescu and I.S. Evans, "Cirque form and development in Romania: Allometry and the buzz-saw hypothesis", Geomorphology, vol. 208, pp. 117-136, 2014.

[6] S.G. Mitchell and E.E. Humphries, "Glacial cirques and the relationship between equilibrium line altitudes and mountain range height”, Geology, vol. 43, pp. 35-38, 2015. doi: 10.113Q/G36180.1

[7] I.S. Evans, A.M. Hall and J. Kleman, "Glacial cirques and the relationship between equilibrium line altitudes and mountain range height: COMMENT", Geology, vol. 43, e366, 2015. doi: 10.1130/G36667C.1

[8] D.L. Egholm, S.B. Nielsen, V.K. Pedersen and J-E. Leseman, "Glacial effects limiting mountain height", Nature, vol. 460, pp. 884-888, 2009.

[9] I.S. Evans, "Inferring process from form: the asymmetry of glaciated mountains", in International Geography 1972, Adams W.P, and Helleiner F,M. (eds). University of Toronto Press: Toronto, vol. 1, 1972, pp. 17-19.

[10] I.D. Barr, J.C. Ely, M. Spagnolo, C.D. Clark, I.S. Evans, X.M. Pellicer, R. Pellitero and B.R. Rea, "Climate patterns during former periods of glacier initiation in Britain and Ireland: inferences from the cirque record" unpublished.

[11] I.S. Evans, "Local aspect asymmetry of mountain glaciation: a global survey of consistency of favoured directions for glacier numbers and altitudes”, Geomorphology, vol. 73, no. 1, pp.166184, 2006.

[12] I.D. Barr and M. Spagnolo, "Glacial cirques as palaeoenvironmental indicators: Their potential and limitations", Earth-Science Reviews, vol. 151, pp.48-78, 2015.

[13] Y. Crest, M. Delmas, R. Braucher, Y. Gunnell, M. Calvet and ASTER Team, "Cirques have growth spurts during deglacial and interglacial periods: Evidence from 10Be and 26Al nuclide inventories in the central and eastern Pyrenees”, Geomorphology, vol. 278, pp. 60-77, 2017. 